\title{
Can Greater Bank Capital Lead to Less Bank Lending?
}

\author{
Virginia Magda Luisa Minni ${ }^{1}$
}

Published online: 16 February 2016

(C) The Author(s) 2016. This article is published with open access at Springerlink.com

JEL $\mathrm{G} 10 \cdot \mathrm{G} 15 \cdot \mathrm{G} 20$

This study assesses the extent to which changes in bank capital exacerbate the cyclical behaviour of credit in the bank lending channel (BLC) of monetary policy. The BLC presumes that expansionary monetary policy directly affects bank loan supply, hence stimulating economic growth through greater investment. However, the current financial crisis has highlighted several weaknesses in the banking sector that could prevent the BLC from functioning properly. I focus on the role of bank capital in Europe.

The key question is whether higher bank capital, instead of triggering greater bank lending, dampens loan growth. The financial crisis and its aftermath have shown that changes in bank capital may have pro-cyclical effects amplified by the Basel II risk-sensitive capital rules (Basel Committee on Banking Supervision consultative document 2009). More specifically, bank capital requirements are likely to rise with increasing risk in economic downturns, at a time when capital is more difficult to raise, which may result in credit contraction and hence a deepening of recessions. If so, higher capital would not dampen losses during economic stagnation periods and rather would amplify the credit restrictions risk, thus contributing to worsening output fluctuations. This potential scenario is of vital concern for scholars and policymakers as it can seriously hamper prospects of faster economic recovery in Europe.

Bank capital and bank lending are endogenous to each other as they are both affected by the financial and economic shocks that are in the error term. Interestingly, this endogeneity has never been explored. Is it a simultaneity problem or omitted relevant variables bias?

Virginia Magda Luisa Minni

minnivirginia@gmail.com

1 Research in Applied Economics, Department of Economics, University of Warwick, Coventry, UK 
The simultaneous equations model is appropriate in case of a simultaneity bias between bank lending and bank capital. The system of structural equations is:

$$
\left[\begin{array}{c}
\Delta \ln (\text { loans })_{i t} \\
\text { capital }_{i t}
\end{array}\right]=\left[\begin{array}{c}
\alpha_{o} \\
\beta_{o}
\end{array}\right]+\left[\begin{array}{cccc}
0 & \alpha_{1} & \alpha_{2} & 0 \\
\beta_{1} & 0 & 0 & \beta_{2}
\end{array}\right]\left[\begin{array}{c}
\Delta \operatorname{1n}(\text { loans })_{i t} \\
\text { capital }_{i t} \\
\Delta i_{m t} \\
r e g_{i t}
\end{array}\right]+\left[\begin{array}{l}
v_{1 i t} \\
v_{2 i t}
\end{array}\right]
$$

with $i=1, \ldots, 41, m=1, \ldots, 13, t=1, \ldots, 10$ where $i$ is the number of banks, $m$ is the number of countries and $t$ is the year. In the equation, $\Delta \ln (\text { loans })_{i t}$ is the change in the natural logarithm of aggregate loans, capital $_{i t}$ is the total regulatory capital ratio, $\Delta i_{m t}$, is the change in the monetary policy rate, and $r g_{i t}$ is regulatory pressure.

The two-stage least squares (2SLS) estimator with bank capital as an endogenous regressor for bank lending is appropriate in the presence of omitted variables bias. The instruments for bank capital are: $r e g_{i t}$, a regulatory pressure variable, $r i s k_{i t}$, a proxy for bank risks and $\operatorname{dep}_{i t}$, the deposit ratio. The first-stage regression is:

$$
\begin{aligned}
\text { capital }_{i t}= & \delta_{0 i}+\delta_{1} \text { reg }_{i t}+\delta_{2} \text { dep }_{i t}+\delta_{3} \text { risk }_{i t}+\delta_{4} \Delta i_{m t-1}+\delta_{5} \Delta \ln (g d p)_{m t-1} \\
& +\delta_{6} \text { crisis }_{t}+\delta_{7} \text { size }_{i t}+\delta_{8} \text { liquidity }_{i t-1}+\eta_{1 i t}
\end{aligned}
$$

Using the fitted values of capital from Eq. (2) we can estimate the second-stage regression:

$$
\begin{aligned}
\Delta \ln (\text { loans })_{i t}= & \varphi_{0 i}+\varphi_{1} \text { capital }_{i t}+\varphi_{2} \Delta i_{m t-1}+\varphi_{3} \Delta \ln (\text { gdp })_{m t-1}+\varphi_{4} \text { crisis }_{t} \\
& +\varphi_{5} \text { size }_{i t}+\varphi_{6} \text { liquidity }_{i t-1}+\eta_{2 i t}
\end{aligned}
$$

where, $\Delta \ln (g d p)_{m t-1}$ is real gross domestic product (GDP) growth, crisis $_{t}$ is a financial crisis dummy, size $_{i t}$ is bank size, and liquidity $_{i t-1}$ is bank liquidity. As a robustness check, I also model the relationship between bank lending and bank capital using the dynamic generalized method of moments (GMM) methodology.

The results for the simultaneous equations model in Eq. (1) suggest that the relationship between bank capital and bank lending is unidirectional: only bank capital has a causal effect on bank lending. Bank capital is statistically significant at the $1 \%$ significance level in the loan growth equation. However, in the capital equation, loan growth is not statistically significant and the size of the coefficient is also tiny.

The results from the 2 SLS model in Eq. (3) constitute the second main finding: banks reduce loan supply in the aftermath of an increase in capital, after controlling for GDP growth as a proxy for loan demand and other bank characteristics. The results are robust to alternative GMM estimations.

The present findings are in contrast to economic theory and suggest that the traditional cycle between greater bank capitalisation and greater lending is impaired. A compelling explanation of the results is that the capital ratio is increased by reducing the risk-weighted assets (RWAs), rather than by injecting new capital into the banks' balance sheet (capital = total capital $/ R W A s)$. Since loans constitute an important part of the RWAs, banks could be increasing the capital ratio by reducing the quantity of 
loans. This feedback cycle becomes more likely when raising new capital is very costly, as in the financial crisis period.

In conclusion, from a policy perspective, the empirical examination feeds into the current debate on new guidelines for capital and banking regulations drawn up by Basel III (Basel Committee on Banking Supervision press release, 12 September 2010). In particular, the results concur with the proposed creation of a counter-cyclical capital buffer.

Acknowledgments I am very grateful to Dr. Alexander Karalis Isaac for his support and encouragement, to Prof. Jeremy Smith for his suggestions and comments and to Dr. Alexander Karalis Isaac and Dr. Gianna Boero for nominating this paper for the Carroll Round. Any errors are my own.

Open Access This article is distributed under the terms of the Creative Commons Attribution 4.0 International License (http://creativecommons.org/licenses/by/4.0/), which permits unrestricted use, distribution, and reproduction in any medium, provided you give appropriate credit to the original author(s) and the source, provide a link to the Creative Commons license, and indicate if changes were made. 